\title{
Dynamics of Nigeria Basic Nursing Students Academic Performance in Weeding Examination
}

Samuel Olukayode Awotona* and Opadoja Funmilayo Abiola

Oyo State College of Nursing and Midwifery Ibadan, Nigeria

*Corresponding author: Samuel Olukayode Awotona, Oyo State College of Nursing and Midwifery Ibadan, Oyo, Nigeria, Tel: +23494132313; E-mail: olukayodeawotona@yahoo.com

Received date: Mar 26, 2018; Accepted date: Feb 28, 2019; Published date: Mar 07, 2019

Copyright: (C) 2019 Awotona SO, et al. This is an open-access article distributed under the terms of the Creative Commons Attribution License, which permits unrestricted use, distribution, and reproduction in any medium, provided the original author and source are credited.

\begin{abstract}
Purpose: The purpose of this study is to ascertain in Nigeria context the perceived barriers to basic nursing students' academic performances in weeding examination.

Methods: One hundred (100) newly admitted students into the Oyo State College of Nursing and Midwifery, Eleyele, Ibadan, Nigeria were used for the study. Survey research method was deployed. The research instrument used was questionnaire which was distributed to each student in order to get their responses.

Results: The study highlights that $80.9 \%$ of the respondent's purpose for studying nursing is to be self-reliant, $(68.1 \%)$ were not professionally proud, while, $(68.1 \%)$ of the respondents were dissatisfied with the basic nursing student lecture mode, $(53.2 \%)$ of the respondents were anxious about course layout, $(49.0 \%)$ of the respondents said that rigorous and overloaded course work affects their performances, $(85.1 \%)$ of the respondents were satisfied with library staff and services.
\end{abstract}

Conclusion: Conclusively, majority of the students were of the opinion that, extra curricula activities distracts, do not accept nursing as a professional calling, parent persuasion hinders them, lecture mode was not right for learning, had anxiety on course layout, rigorous and overloaded course and inadequate facilities was a bane of failure. Further studies needed to be conducted on curriculum and teaching methods for nursing students.

Keywords:

College library; Weeding; Nursing profession; Nursing and midwifery council of Nigeria; Indexing; Students

\section{Introduction}

Examination is an integral part of the educational system used to measure a student's progress towards predetermined objectives. It is a process for testing the abilities or achievement of the student in any area of academic programme. The nursing pre-entrance examination is a prerequisite for prospective students to complete standardized entrance exams. Weeding Examination is an examination that is conducted for newly admitted nursing student in their first three months and six months in school, this serves as a requisite for full admittance into studying nursing course. It is conducted by various schools of nursing colleges that are offering courses leading to the award of Registered Nurse Certificate. Weeding Examination is a method or process by which the College trims down the size of the student intake to the required number for Nursing and Midwifery Council of Nigeria indexing process. The Weeding Examination is conducted periodically within three and six months. Due to the competitiveness and high standard of the nursing profession, it is required of any nursing students to pass in order to be presented to the Nursing and Midwifery Council of

Nigeria for indexing, the College embarks on the first phase of Weeding Examination at three month to see the preparedness of the intake for the profession, those who fails will be weeded out after which the successful one will continue with their training and this will lead to the second phase which comes after the six months stay in the College. Those that are successful are referred to as bonafide students of the College. They will be capped or matriculated for formal presentation to the Nursing and Midwifery Council of Nigeria for indexing. These students will complete their three years course duration in the College once they are able to scale their sessional examination and eventually will sit for the final Examinations of Nursing and Midwifery Council of Nigeria.

In another dimension, Kakuk et al. [1], pointed that the library plays a very important role in providing variety of print and electronic resources that will assist examination preparation. It also assist in locating the most recent materials as a well as suggest additional examination preparation materials. Meanwhile, research has revealed that various factors affect the academic performance of students sitting for the Weeding Examination of the College. These factors include academic competence, individual intelligence, physical and mental health alertness, anxiety, motivation, interest in the profession, study habit, facilities in the college which include both the living and educational facilities. Other reason is lack of awareness of what it entails to be a student Nurse. Most students when admitted to the College are over elated and unprepared for the intelligent, physically and mentally alertness required in medicine. Marquez et al. [2] noted 
Page 2 of 6

that a student who is successful in his desired career has a good study habits. With this, she stated that students should apply these habits to all their classes. She also advised that the students should not try to study all the subjects in a single period. Having quality teachers to teach the students could be seen as a factor affecting the performance of the students. The success of any programme is conditioned by the ability of the teacher to teach the students to understand and if there is failure at this stage, the whole structure will fail.

Marbas et al. [3] posited that teachers at all levels utilize a variety of instructional materials such as textbooks, presentations and handouts to enhance the quality of their lessons. The quality of those materials directly impacts the quality of teaching. Knowing how to find the best instructional materials is a valuable skill for a teacher to have. The importance of Instructional Materials or Educational resources is to improve students' knowledge, abilities, and skills, to monitor their assimilation of information, and to contribute to their overall development and upbringing. It also clarifies important concepts to arouse and sustain student's interests, give all students in a class the opportunity to share experiences necessary for new learning, help make learning more permanent. With the wise selection and use of a variety of instructional materials or audio- visual materials, experiences may be provided to develop understanding. Learning facilities is very important in the academic performance of the students if the learning facilities are poor the students performance is significantly correlated with the satisfaction of the academic environment and facilities of the library. The academic environment is the effective-variables for any students to perform academically.

\section{Research Question}

The study came up with the following questions in other to elicit the required answers:

1. Did students interaction affects academic performances?

2. What is the motive of studying nursing as a course?

3. In what way did the course content affects academic performance?

4. Are the library resources and personnel adequate?

\section{Research Objectives}

The main objectives of this research are to explore the factors affecting the academic performance of the Basic Nursing Students in Weeding Examination. The specific objectives are:

1. To find out if the interaction between student affects academic performance.

2. To ascertain the motive for studying affect academic performance.

3. To determine the relationship of course content to academic performance.

4. To determine the extent at which the library resources and personnel affects academic performances.

\section{Research Design}

Survey research method was deployed. The research instrument used waslack of interest in learning, poor performance in examination. Bashir et al. [4] defined anxiety as a basic human emotion consisting of apprehension and uncertainty that typically appears when an individual perceives an occurrence as being a threat to the ego or self esteem. Learning difficulties will create students' anxiety of feeling discomfort, which means that feeling anxious in the classroom does not improve learning. Moadeli et al. [5] pointed that students who felt satisfied and had low levels of anxiety achieved a higher academic performance. It is common for students to perform poorly when they experience pressure with their tasks and when they experience high level of anxiety during their studies, Anxiety among students are created by insensible teaching or an over demanding curriculum/ syllabus.

Among factors that affect academic performance of students is motivation, motivation is very important for different achievement or success. Motivation is a thought of inner state of need or desire that activates an individual to do something to satisfy them. Williams and Olofinsawe et al. [6] gives a proposed definition of motivation as a state of cognitive and emotion arousal, which leads to a conscious decision to act, and gives rise to a period of sustained intellectual and physical effort in order to attain a previously set goal. Tutors needs to motivate students to cultivate effective study pattern to have a good academic performance. Ayodele et al. [7] posited that successful academic performance depends on effective studying and motivational strategies.

\section{Population}

The study was conducted using population sample of one hundred (100) newly admitted student into the Oyo State College of Nursing and Midwifery, Eleyele, Ibadan

\section{Results}

The study reveals in two categories the factors that affect academic performance of the basic nursing students, the interaction-motivation and course layout cum satisfaction with the College Library. So the various factors enumerated were examined viz-a-viz these categories:

\begin{tabular}{|l|l|}
\hline Factors & $\%$ \\
\hline Belong to a club & \\
\hline Yes & 70.2 \\
\hline No & 27.7 \\
\hline Undecided & 2.1 \\
\hline Total & 100 \\
\hline Financially Beneficial & \\
\hline Yes & 8.5 \\
\hline No & 74.5 \\
\hline Undecided & 8.5 \\
\hline Total & 91.5 \\
\hline Missing & 8.5 \\
\hline Total & 100 \\
\hline Academically Beneficial & 29.8 \\
\hline Yes & \multicolumn{2}{|l|}{} \\
\hline
\end{tabular}


Page 3 of 6

\begin{tabular}{|l|l|}
\hline No & 48.9 \\
\hline Undecided & 8.5 \\
\hline Total & 87.2 \\
\hline Missing System & 12.8 \\
\hline Total & 100 \\
\hline
\end{tabular}

Table 1: Summary of student interaction.

Table 1 shows that the majority, $70.2 \%$ of the respondents belong to a club or association. While, $27.7 \%$ do not belong to any association, the degree of involvement in association activities might explain the students' magnitude of distractions. It is worthy of note that only $8.5 \%$ of the respondents admit that association is financially beneficial; while 74.5\% (majority) do not benefit financially from the association. Meanwhile, $29.8 \%$ of the respondents said that their association was academically beneficial while $48.9 \%$ (majority) do not derive academic benefit from their association, this corroborate the earlier assertion of involvement which necessitate unnecessary distractions.

\begin{tabular}{|l|l|}
\hline Factors & \multicolumn{1}{l|}{ Percentage } \\
\hline Self- Reliance & 80.9 \\
\hline Yes & 10.6 \\
\hline No & 2.1 \\
\hline Undecided & 93.6 \\
\hline Total & 6.4 \\
\hline Missing System & 100 \\
\hline Total & \multicolumn{2}{|l|}{} \\
\hline Nursing is a calling & 2.1 \\
\hline Yes & 89.4 \\
\hline No & 8.5 \\
\hline Undecided & 100 \\
\hline Total & \multicolumn{2}{|l|}{} \\
\hline Profession to be proud of & 23.4 \\
\hline Yes & 68.1 \\
\hline No & 4.3 \\
\hline Undecided & 95.1 \\
\hline Total & 4.3 \\
\hline Missing System & 100 \\
\hline Total & \multicolumn{2}{|l|}{} \\
\hline Parent Persuasion & \\
\hline Yes & \\
\hline No & \\
\hline Undecided & \\
\hline
\end{tabular}

\begin{tabular}{|l|l|}
\hline Total & 93.6 \\
\hline Missing System & 6.4 \\
\hline Total & 100 \\
\hline I don't have any other profession & \multicolumn{2}{|l|}{} \\
\hline Yes & 72.3 \\
\hline No & 4.3 \\
\hline Undecided & 6.4 \\
\hline Total & 83 \\
\hline Missing System & 17 \\
\hline Total & 100 \\
\hline
\end{tabular}

Table 2: Summary of purpose of study.

Table 2 shows that $80.9 \%$ of the respondent's purpose for studying nursing is to be self-reliant while $10.6 \%$ of the respondents are not studying for self-reliance; $2.1 \%$ of the respondents had nursing as a calling as a purpose for studying it while majority (89.4\%) of the respondents do not believe that it is a calling; $23.4 \%$ of the respondents were motivated because nursing is a profession they can be proud of while majority $(68.1 \%)$ were not motivated by nursing being a profession they can be proud of; Majority $(82.7 \%)$ of the respondents were motivated by parent persuasion while $4.3 \%$ were not motivated by their parent; Majority (72.3\%) of the respondents were motivated to study nursing because they do not have any other profession while $4.3 \%$ were not motivated because they do not have any other profession, it explained that most of the students admitted into the college had a wrong purpose and motive for studying nursing while only few had the right purpose. Table 3 shows that majority (53.2\%) of the respondents were anxious about course layout, while $36.2 \%$ were not anxious; majority (49.0\%) of the respondents said that rigorous and overloaded course work affects their performance while $46.8 \%$ said that rigorous and overloaded course work do not affect them; majority (68.1\%) of the respondents said that lecture mode affects their academic performance while $23.4 \%$ said that lecture mode do not affects them, this says that the lecturer had to adopt teaching method that will allow the students to assimilate better, majority $(51.1 \%)$ of the respondents said that inadequate facilities affects their performance while $31.9 \%$ said they were not affected by inadequate facilities.

\begin{tabular}{|l|l|}
\hline Factors & Percentage \\
\hline Anxiety & \\
\hline Yes & 53.2 \\
\hline No & 36.2 \\
\hline Undecided & 6.4 \\
\hline Total & 95.8 \\
\hline Missing System & 4.2 \\
\hline Total & 100 \\
\hline Rigorous and overloaded course work & \multicolumn{2}{|l|}{} \\
\hline Yes & 49 \\
\hline
\end{tabular}


Citation: Awotona SO, Abiola OF (2019) Dynamics of Nigeria Basic Nursing Students Academic Performance in Weeding Examination. J Nurs Care 8: 473. doi:10.4172/2167-1168.1000473

Page 4 of 6

\begin{tabular}{|l|l|}
\hline No & 46.8 \\
\hline Total & 95.7 \\
\hline Missing System & 4.3 \\
\hline Total & 100 \\
\hline Lecture mode & 23.4 \\
\hline Yes & 68.1 \\
\hline No & 23.4 \\
\hline Undecided & 4.3 \\
\hline Total & 95.7 \\
\hline Missing System & 4.3 \\
\hline Total & 100 \\
\hline Inadequate facilities & 87.2 \\
\hline Yes & 51.1 \\
\hline No & 31.9 \\
\hline Undecided & 6.4 \\
\hline Total & 89.4 \\
\hline Missing System & 10.6 \\
\hline Total & 100 \\
\hline
\end{tabular}

Table 3: Summary of course layout.

\begin{tabular}{|l|l|}
\hline Factors & Percentage \\
\hline Availability of Textbooks & \\
\hline Very Satisfied & 31.9 \\
\hline Fairly Satisfied & 53.2 \\
\hline Very Dissatisfied & 4.3 \\
\hline Fairly Dissatisfied & 4.3 \\
\hline Total & 94.6 \\
\hline Missing System & 6.4 \\
\hline Total & 100 \\
\hline Opening Hour & 49 \\
\hline Very Satisfied & 51.1 \\
\hline Fairly Satisfied & 34 \\
\hline Very Dissatisfied & 14.9 \\
\hline Fairly Dissatisfied & 6.4 \\
\hline Total & 87.2 \\
\hline Missing System & 100 \\
\hline Total & \\
\hline Range of Journal & \\
\hline & \\
\hline
\end{tabular}

\begin{tabular}{|c|c|}
\hline Very Satisfied & 23.4 \\
\hline Fairly Satisfied & 42.6 \\
\hline Very Dissatisfied & 14.9 \\
\hline Fairly Dissatisfied & 6.4 \\
\hline Total & 87.2 \\
\hline \multicolumn{2}{|l|}{ Borrowing of Books } \\
\hline Very Satisfied & 23.4 \\
\hline Fairly Satisfied & 42.6 \\
\hline Very Dissatisfied & 19.1 \\
\hline Fairly Dissatisfied & 10.6 \\
\hline Total & 95.7 \\
\hline Missing System & 4.3 \\
\hline Total & 100 \\
\hline \multicolumn{2}{|l|}{ Quietness } \\
\hline Very Satisfied & 72.3 \\
\hline Fairly Satisfied & 19.1 \\
\hline Very Dissatisfied & 2.1 \\
\hline Fairly Dissatisfied & 4.3 \\
\hline Total & 97.9 \\
\hline Missing System & 2.1 \\
\hline Total & 100 \\
\hline \multicolumn{2}{|l|}{ Study Environment } \\
\hline Very Satisfied & 70.2 \\
\hline Fairly Satisfied & 23.4 \\
\hline Very Dissatisfied & 2.1 \\
\hline Fairly Dissatisfied & 20.2 \\
\hline Total & 95.7 \\
\hline Missing System & 4.3 \\
\hline Total & 100 \\
\hline \multicolumn{2}{|c|}{ Behaviour of other user } \\
\hline Very Satisfied & 42.6 \\
\hline Fairly Satisfied & 38.3 \\
\hline Very Dissatisfied & 2.1 \\
\hline Fairly Dissatisfied & 4.3 \\
\hline Total & 87.2 \\
\hline Missing System & 12.8 \\
\hline Total & 100 \\
\hline Access support & \\
\hline
\end{tabular}


Page 5 of 6

\begin{tabular}{|c|c|}
\hline Very Satisfied & 44.7 \\
\hline Fairly Satisfied & 25.5 \\
\hline Very Dissatisfied & 10.6 \\
\hline Fairly Dissatisfied & 2.1 \\
\hline Total & 83 \\
\hline Missing System & 17 \\
\hline Total & 100 \\
\hline \multicolumn{2}{|l|}{ Photocopying } \\
\hline Very Satisfied & 21.3 \\
\hline Fairly Satisfied & 27.7 \\
\hline Very Dissatisfied & 25.5 \\
\hline Fairly Dissatisfied & 6.4 \\
\hline Total & 80.9 \\
\hline Missing System & 19.1 \\
\hline Total & 100 \\
\hline \multicolumn{2}{|c|}{ Library Environment Conduciveness } \\
\hline Very Satisfied & 53.2 \\
\hline Fairly Satisfied & 36.2 \\
\hline Very Dissatisfied & 2.1 \\
\hline Fairly Dissatisfied & 4.3 \\
\hline Total & 95.7 \\
\hline Missing System & 4.3 \\
\hline Total & 100 \\
\hline \multicolumn{2}{|c|}{ Library Staff Competency } \\
\hline Very Satisfied & 59.6 \\
\hline Fairly Satisfied & 28.9 \\
\hline Very Dissatisfied & 2.1 \\
\hline Fairly Dissatisfied & 2.1 \\
\hline Total & 93.6 \\
\hline Missing System & 6.4 \\
\hline Total & 100 \\
\hline \multicolumn{2}{|c|}{ Satisfaction with Staff discharge of duties } \\
\hline Very Satisfied & 51.1 \\
\hline Fairly Satisfied & 40.4 \\
\hline Very Dissatisfied & 2.1 \\
\hline Fairly Dissatisfied & 2.1 \\
\hline Total & 95.7 \\
\hline Missing System & 4.3 \\
\hline
\end{tabular}

\begin{tabular}{|l|l|}
\hline Total & 100 \\
\hline Library material up datedness & \\
\hline Very Satisfied & 27.7 \\
\hline Fairly Satisfied & 51.1 \\
\hline Very Dissatisfied & 12.8 \\
\hline Fairly Dissatisfied & 4.3 \\
\hline Total & 95.7 \\
\hline Missing System & 4.3 \\
\hline Total & 100 \\
\hline
\end{tabular}

Table 4: Summary of satisfaction with the college library.

Table 4 shows that, majority $(85.1 \%)$ of the respondents said were very satisfied with available course textbooks in the library while $10.7 \%$ were dissatisfied; $85.1 \%$ of the respondents were satisfied with the opening hour while $10.7 \%$ were dissatisfied; $66.0 \%$ of the respondents were satisfied with the range of journal available in the library while $21.3 \%$ were dissatisfied; $66.0 \%$ of the respondents were satisfied with the book borrowing system while $29.7 \%$ were dissatisfied; $91.4 \%$ of the respondents were satisfied with the quietness of the library while $6.4 \%$ were dissatisfied; $73.6 \%$ of the respondents were satisfied with the study environment while $22.3 \%$ were dissatisfied; $80.9 \%$ of the respondents were satisfied with the behaviour of other users while $6.4 \%$ were dissatisfied; $70.2 \%$ of the respondents were satisfied with access support provided while $12.7 \%$ were dissatisfied; $59.0 \%$ of the respondents were satisfied with photocopying services provided while $31.9 \%$ were dissatisfied; $89.4 \%$ of the respondents were satisfied with the conduciveness of the library environment while $6.4 \%$ were dissatisfied; $89.4 \%$ of the respondents were satisfied with library staff competency in their duties while $4.2 \%$ were dissatisfied; $91.5 \%$ of the respondents were satisfied with library staff ways of discharging their duties while $4.2 \%$ were dissatisfied; $27.7 \%$ of the respondents were very satisfied with the library resources, $78.8 \%$ were satisfied while $17.1 \%$ were dissatisfied.

\section{Discussion of Findings}

The study shows that $70.2 \%$ of the respondents belong to a club or association which shows that most of the students are distracted from their academics and $74.5 \%$ also do not derive academic benefit, therefore it is a point to note by the students that ant extra-curricular activities that does not bring academic benefits should be discard off.

The study further revealed that $89.4 \%$ of the respondents do not believe that nursing is a calling; $68.1 \%$ were not motivated by nursing being a profession they can be proud of; $82.7 \%$ of the respondents were motivated by parent persuasion; $72.3 \%$ were motivated to study nursing because there is no other profession for them to take up. This indeed shows that student's interest plays a pivotal role in how they fare in whatever profession or courses they want to embark upon.

The study also revealed that $53.2 \%$ of the respondents were anxious about course layout, $49.0 \%$ said that rigorous and overloaded course works affects their performances; $68.1 \%$ of the respondents said that lecture mode affects their academic performances, $51.0 \%$ of the respondents said that inadequate facilities affects their performances. 
Page 6 of 6

Lastly the study showed that $85.1 \%$ of the respondents said they were satisfied with available course textbooks in the library; $85.1 \%$ were satisfied with the opening hour; $66.0 \%$ of the respondents were satisfied with book borrowing system; $91.4 \%$ were satisfied with the guidelines of the library; $73.6 \%$ of the respondents were satisfied with the behavior of other users; $70.2 \%$ of the respondents were satisfied with access support provided in the library; $59.0 \%$ were satisfied with photocopying services; $89.4 \%$ of the respondents were satisfied with the conduciveness of the library environment; $89.4 \%$ of the respondents were satisfied with the library staff competency; $91.5 \%$ of the respondents were satisfied with the library resources.

\section{Conclusion}

It can be concluded that club or associations distracts students from their academics and do not bring any benefits to them both academically and financially.

It can also be inferred from the study that students attitudes towards nursing education such as seeing it as a calling, a profession they can be proud of can go a long way in their academic performances. It can also be said that anxiety about course layout, rigorous and overloaded course works, lecture mode, inadequate facilities affects student's performances.

Lastly, library that has all the facilities such as good course textbook, good opening hour, sound book borrowing system, quiet and conducive environment, library staff with adequate knowledge and skills goes a long way in boosting student's performances in academic pursuance.

\section{Recommendation}

The following recommendation can be made based on the study conducted:
I. Students should cut down their extra curricula involvement.

II. See nursing as a calling rather than a stop gap profession

III. There should be constant review of the nursing curriculum by the nursing council to reflect current needs of the profession and make the course load to be less vigorous.

IV. Lecturers should adopt multifaceted teaching methods to covey ideas and concept in the profession to the students.

V. Adequate facilities should be provided by the College management to help the student bed-in into the course.

VI. The library should be adequately stocked and students encouraged in using the library as a source of information search than their phones and other unmonitored source.

\section{References}

1. Smith KDJ (2012) Nursing Pre-entrance examination review materials.

2. Marquez MS (2009) Influence of Time-on-phone on Undergraduates Academic Achievement in Nigerian Universities. AJES 5: 564-567.

3. Marbas J (2017) The importance of instructional materials.

4. Bashir I, Mattoo NH (2012) A study of study habits and academic performance among adolescents (14-9) years. International Journal of Science Tomorrow 1: 1-8.

5. Moadeli Z, Ghazannfari-Hesamabedi MA (2005) Survey on students' exam anxiety in the Fatemeh (P.B.A.H) College of Nursing and Midwifery. Journal of Strides in Development of Medical Education 1: 65-72.

6. Olofinsawe AA, Ajayi PO (2008) Students' utilization of academic libraries: a case study of Federal University of Technology, Akure, between 2001-2005. Asian Journal of Information Technology 7: 172-174.

7. Ayodele CS, Adebiyi DR (2013) Study habits as influence of academic performance of students nurses of Banquet State University. IJNSS 5: 60-65. 